\title{
Petroleum Geochemistry Regional Study of Murzuq Basin: Insights from Biomarkers Characteristic, Stable Carbon Isotope and Environmental Characterization
}

\section{Aboglila S*, Albaghdady A, Farifr E and Alborky A}

Science Faculty, Azzaytuna University, Libya

*Corresponding author: Salem Aboglila, Science Faculty, Azzaytuna University, Libya, Tel: 00218913700361; Email: salem.aboglila@gmail.com

\section{Research Article \\ Volume 4 Issue 1}

Received Date: December 23, 2019

Published Date: January 31, 2020

DOI: $10.23880 /$ ppej-16000215

\section{Abstract}

This search aims to apply developed geochemical methods to a number of oils and source rock extracts to better establish the features of ancient environments that occurred in the Murzuq basin. Geochemical and geophysical approaches were used to confirm further a source contribution from other Paleozoic formations to hydrocarbon accumulations in the basin. One hundred and forty rock units were collected from B1-NC151, D1-NC174, A1-NC 76, D1-NC 151, F1-NC58, A1-NC 186, P1-NC 101, D1-NC 58, H1-NC58 and A1-NC58 wells. Seven crude oils were collocated A1-NC186, B1-NC186, E2-NC101, F3-NC174, A10-NC115, B10-NC115 and H10-NC115 wells. A geochemical assessment of the studied rocks and oils was done by means of geochemical parameters of total organic carbon (TOC), Rock-Eval analysis, detailed-various biomarkers and stable carbon isotope. The TOC values from B1-NC151 range $0.40 \%$ to $8.5 \%$, A1-NC186 $0.3 \%$ and 1.45 , A1-NC76 $0.39 \%$ to $0.74 \%$, D1-NC151 $0.40 \%$ to $2.00 \%$ to F1-NC58 $0.40 \%$ to $1.12 \%$. D1_NC174 $0.30 \%$ to $10 \%$, P1-NC101 $0.80 \%$ to $1.35 \%$, D1-NC58 $0.5 \%$ to $1.10 \%$, H1-NC58 $0.20 \%$ to $3.50 \%$, A1-NC58 $0.40 \%$ to $1.60 \%$. The categories of organic matter from rock-eval pyrolysis statistics point to that type II kerogen is the main type, in association with type III, and no of type I kerogen recognized. Vitrinite reflectance (\%Ro), Tmax and Spore colour index (SCI) as thermal maturity parameters reflect that the measured rock units are have different maturation levels, ranging from immature to mature sources. acritarchs distribution for most samples could be recognized and Palynomorphs are uncommon. Pristane to phytane ratios $(>1)$ revealed marine shale to lacustrine of environmental deposition. The Stable carbon isotope $\left(\delta^{13} \mathrm{C}\right)$ values of seven rock-extract samples are $-30.98 \%$ and $-29.14 \% 0$ of saturates and $-29.86 \%$ to $-28.37 \%$ aromatic fractions. The oil saturate hydrocarbon fractions range between $-29.36 \%$ o to $-28.67 \%$ and aromatic are among $-29.98 \%$ to $-29.55 \%$. The $\delta{ }^{13} \mathrm{C}$ data in both rock extractions and crude oils are closer to each other, typical in sign of Paleozoic age. It is clear that the base of Tanezzuft Formation (Hot shale) is considered the main source rocks. The Devonian Awaynat Wanin Formation as well locally holds sufficient oil prone kerogen to consider as potential source rocks. Ordovician Mamuniyat Formation shales may poorly contain oil prone kerogen to be addressed in future studies. An assessment of the correlations between the oils and potential source rocks and between the oils themselves indicated that most of the rocks extracts were broadly similar to most of the oils and supported by carbon stable isotope analysis results.

Keywords: Murzuq Basin; Biomarkers; Crude Oils; Source Rocks; Hot Shale 


\section{Petroleum \& Petrochemical Engineering Journal}

\section{Introduction}

Oil exploration in Murzuq basin began in 1957 and has recently became the focus of petroleum exploration efforts in the most of region. While numerous discoveries were completed in many portions of the basin however the rest of the basin remains typically needs more studies. Such as, lack in information on the basin-wide parameters of the petroleum systems acting in the area by Hallett D [1]. The basin-wide understanding in relation to improvement of knowledge on the provincial aspects of the petroleum geochemistry of Murzuq Basin, in particular the assessment of petroleum systems, the potential and distribution source rocks characteristics. Thermal maturity and source quality in selected oil wells from Murzuq Basin described in study by Archer R [2]. Stratigraphic report and hydrocarbon potential of the of Silurian shale of the Paleozoic Tanezzuft Formation reported by Aziz A [3] as well the geological aspect and hydrocarbon occurrences in the Basin was published [4]. In study of geochemical analysis and thermal history modeling of concession NC174 in Murzuq Basin illustrated that the hot shale facies at the base of the Silurian Tanezzuft Formation as the principal source rock [5]. The hot shale is distinguishing in the subsurface data by Aboglila S, et al. [6], the most rock Kerogen is type II, the Hot Shale Member (Lower Silurian) at the base of the Tanezzuft Formation is a high quality, oil source rock which is currently at oil maturity and has not yet gone in the gas window in addition to Vitrinite Reflectance (\% Ro) and Spore Coloration Index (SCI) of the Hot Shale Member, indicted that the hot shale is higher maturity than other sediments. Trailed by oil geochemical search published by Aboglila S, et al. [7], revealed non-biodegradation in all examined crude oils, alkane n-C19 peak, a dominance of C29 over C27 and C28 steranes and light carbon isotope that studied oils are sourced from Lower Palaeozoic facies. This study presented that the depositional environment of studied oils is marine shale deposited under sub-oxic conditions. Studies by Aboglila S, et al. [7] in NC115, confirmed that the Tanezzuft formation includes organic-rich shale facies (Hot Shale) have fair to very good source potential. However, in the region possible hydrocarbon contribution from the Upper Devonian Awaynat Wanin Formation and the Lower Carboniferous Mrar Formation to organic matter accumulations in Murzuq basin, due to high values of maturity parameters such Tmax, Ro\%, SCI and elevated values of TOC in addition to Dark-grey shale lithology were established [6]. The present paper is petroleum geochemistry regional study involves numbers of concessions in the Murzuq Basin. This search aims to apply developed geochemical methods to a number of oils and source rock extracts to better establish the features of ancient environments that occurred in the basin. Both individual components and their relative contributions to the overall composition of the oils and rocks will be established. Geochemical parameters of TOC, RockEval analysis, detailed-various biomarkers and stable carbon isotope of source rock and crude oils will be delineated to confirm further contributions from another Paleozoic formations to hydrocarbon accumulations in the basin and to improve understanding on the regional characteristics of the petroleum geochemistry in particular source rocks assessment, distribution, quality, modeled maturity and oilsource rocks correlations.

\section{Geological Setting}

The Murzuk Basin is an intra-cratonic sag basin located inside East Saharan Craton on the Saharan Platform of North Africa and also is one of the three major Libyan basins (Figure 1). The stratigraphic column in the Murzuq Basin comprises deposits range from the Precambrian to the Quaternary age. A basement comprises Precambrian metasediments, overlain by Cambrian fluvial and braid plain quartzite of the Hasawnah Formation [8]. The overlying Lower Ordovician Ash Shabiyat Formation. is represented via similar facies however the conformable Middle Ordovician, Hawaz Formation is characterized by sandy, transgressiveregressive marine sequences through intense bioturbation. The Middle Ordovician is extremely incised due to corrosion, strong low stand. The Upper Ordovician, MelezShuqran and Mamuniyat Formation, fillet the incised valleys and rest on the Hawaz Formation, represented by diamictite and slumped delta front shales in locally present, overstepped by cut cycle of coarsening up marine and fluviodeltaic sediments of the Mamuniyat Formation [1]. The Ordovician unit is truncated at the Taconian, which exhibits paleorelief under transgressed sequence comprising the Lower Silurian Tanezzuft Formation. These sediments deposited in restricted to open marine conditions present organic rich shale levels at the base termed. The Tanezzuft Formation marks up into the overlying Acacus Formation, a regressive unit of finegrained sandstone that forms a prominent escarpment in outcrop at the western margin of the basin [3]. Above this rock, the Devonian is represented by sequences of shale minor, and carbonates sandstones. Two units termed the Basal Devonian Sands, have been recognized as secondary reservoir objective and separated by regional extensive shale. The Basal Devonian Sands section is overlain and be in part laterally equivalent to the Awaynat Wanin Formation. The latest Devonian (Strunian) Tahara Formation. Lower Carboniferous (Marar Formation), comprising deltaic and shallow marine shales with inter bedded sandstones, likely minor reservoirs at the northern border of the basin [9]. The Marara Formation overlain by inlet mudstones and algal limestone of the Collenia Beds, in turn by the Assedjefar and Dembaba Formations. The over lying continental redbed sequence contain Upper Carboniferous at the base then mainly Triassic, Jurassic and Lower Cretaceous sediments. Quaternary - Recent Aeolian dune as sands and alluvium cover large parts of the basin [10]. 


\section{Petroleum \& Petrochemical Engineering Journal}

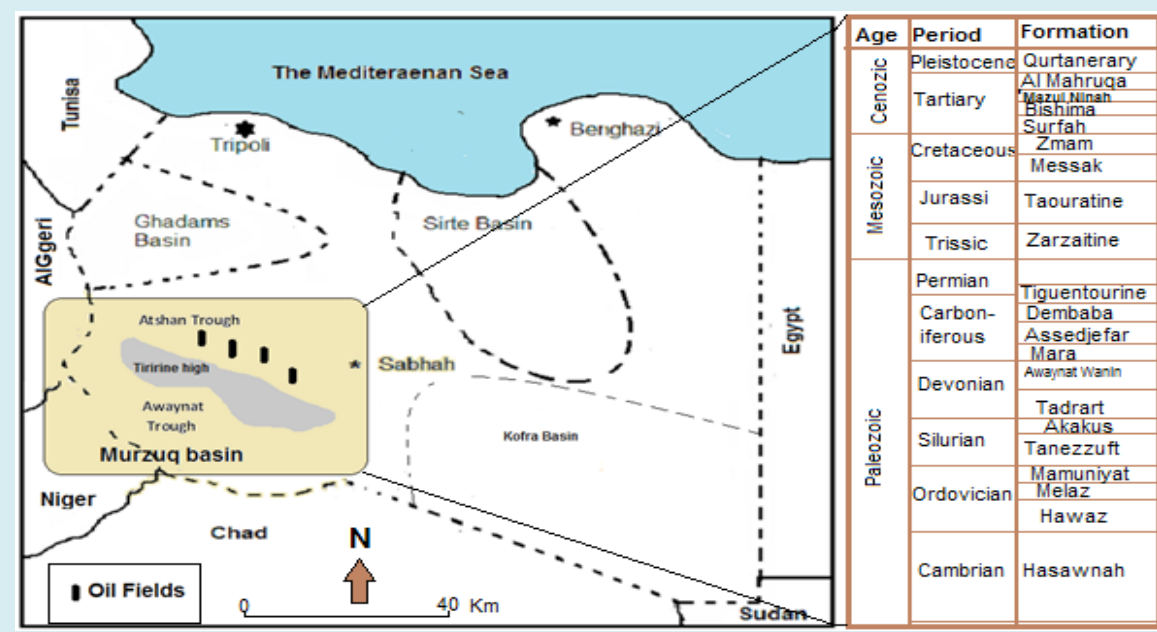

Figure 1: Map shows the location of the Murzuq Basin and stratigraphic column Modified from Aboglila S, et al. and Rusk DC $[6,7,11]$.

\section{Materials and Methods}

\section{Rock Samples}

One hundred and forty sediment samples from ten wells in different concessions were collected from Murzuq Basin for total organic carbon (TOC) and Rock - Eval Pyrolysis analyses. Pyrolysis analysis was carried out on samples with total organic carbon (TOC) more than $1 \%$.

\section{Preparation of Cutting Samples}

The cutting samples were thoroughly washed with doubly distilled water and dried at room temperature prior to analysis. Next Rock-Eval pyrolysis and TOC analysis (see below), a suite of representative samples was selected for more detailed organic geochemical analysis. These samples were ground to a fine powder (particle size of $<150 \mu \mathrm{m}$ ) using a ring-mill (Rocklabs). Ground samples passed through the sieves were used for analysis.

\section{Microscopy Assessment}

Microscopy was used for kerogen typing by palynofacies analysis and spore color index (and acritarchs) measurements. Acritarch color was converted to the spore color equivalents then the Spore Color Index reference slides used in this investigation were labeled based on chart of Collins A [12].

\section{Rock-Eval Pyrolysis and Total Organic Carbon (TOC) Measurements}

Rock-Eval pyrolysis of ground cutting (10 - $50 \mathrm{mg}$ ) was carried out on a Girdel Rock-Eval instrument, although the TOC was measured on a Leco device. Samples with low TOC values $<1.0 \%$ were considered unsuitable for Rock-Eval pyrolysis and therefore not subjected to further analyses.

\section{Solvent Extraction and Isolation of the Maltenes}

Seven cuttings samples from representative sediments were selected for solvent extraction based on TOC values. Approximately 10 - $20 \mathrm{~g}$ of ground sediment was extracted in an ultrasonic bath for two hours using a 9:1 mixture of dichloromethane (DCM) and methanol $(\mathrm{MeOH})$. The solvent extract was then filtered and extra solvent removed by carefully heating on a sand bath $\left(60^{\circ} \mathrm{C}\right)$ to obtain the bitumen. In brief, about $10-20 \mathrm{mg}$ was applied to the top of a small column $(5.5 \mathrm{~cm} \times 0.5 \mathrm{~cm}$ i.e. $)$ of activated silica gel $\left(120{ }^{\circ} \mathrm{C}, 8\right.$ h) [13]. The aliphatic hydrocarbon (saturated) fraction was eluted with $n$-pentane $(2 \mathrm{~mL})$; the aromatic hydrocarbon fraction with a mixture of n-pentane and DCM $(2 \mathrm{~mL}, 7: 3$ $\mathrm{v} / \mathrm{v}$, ); and the polar (NSO) fraction with a mixture of DCM and $\mathrm{MeOH}(2 \mathrm{~mL}, 1: 1 \mathrm{v} / \mathrm{v})$.

\section{Gas Chromatography-Mass Spectrometry (GC-MS)}

Aliphatic and aromatic fractions were analysed by GC-MS using a Hewlett Packard (HP) 5973 mass-selective detector (MSD) interfaced to a HP6890 gas chromatograph (GC). A HP5MS (Jand WScientific) GC column (5\% phenylmethylsiloxane stationary phase) was used with helium as the carrier gas. In brief, the $\mathrm{GC}$ oven was programmed from $40{ }^{\circ} \mathrm{C}$ to $310{ }^{\circ} \mathrm{C}$ at $3^{\circ} \mathrm{C} / \mathrm{min}$, after which it was held isothermal for $30 \mathrm{~min}$. Samples were dissolved in $n$-hexane and introduced by the HP6890 auto-sampler into a split-splitless injector operated in the pulsed-splitless mode. Biomarker data were acquired in a full-scan mode (m/z 50 - 500).

\section{GC-Isotope Ratio Mass Spectrometry (GC-IR-MS)}

For carbon isotope measurements, a Hewlett Packard 


\section{Petroleum \& Petrochemical Engineering Journal}

(HP) 5890 gas chromatograph (GC) with auto sampler was used in tandem with a Micromass isotope ratio mass spectrometer (IR-MS). The $\delta^{13} \mathrm{C}$ data were obtained by integrating the ion currents for masses 44,45 and 46 from the $\mathrm{CO}_{2}$ produced by oxidation of each chromatographically separated component, after passing through a quartz furnace packed with copper oxide pellets heated at $850^{\circ} \mathrm{C}$.

\section{Separation-Analysis of Crude Oils}

Seven crude oils were collocated and separated into three fractions using a column chromatographic method [13]. 10 to 20 mgs of crude oil were applied to the top of a small column $\left(5.5 \mathrm{~cm} \times 0.5 \mathrm{~cm}\right.$ i.d.) of activated silica gel $\left(120^{\circ} \mathrm{C}, 8 \mathrm{~h}\right)$. The aliphatic hydrocarbon (saturated) fraction was eluted with $\mathrm{n}$-pentane $(2 \mathrm{~mL})$; the aromatic hydrocarbon fraction with a mixture of n-pentane and DCM $(2 \mathrm{~mL}, 7: 3 \mathrm{v} / \mathrm{v}$,$) ; and the polar$ (NSO) fraction with a mixture of DCM and $\mathrm{MeOH}(2 \mathrm{~mL}, 1: 1$ $\mathrm{v} / \mathrm{v}$ ). The rest steps of oil geochemistry analysis were similar technique above, used with source rocks (sections 3.5, 3.6 and 3.7).

\section{Results and Discussion}

The main source rocks in NC 115 and over all Murzuq Basin is the Hot Shale Member (Lower Silurian) at the base of the Tanezzuft Formation is a high level source rock $[6,14]$. The Tmax of most Carboniferous and Devonian samples dropped in mature side and potential yields exceed 2000 ppm and aromatic hydrocarbon ratios revealed that the Hot shale member high aromatic content at phase of mature whereas rest formations ranged from immature to mature. Furthermore, investigate crude oils samples from same concession, the conclusion revealed the studied oils sourced from Lower Paleozoic facies $[7,14]$. Based on the dominance of $\mathrm{C}_{29}$ over $\mathrm{C}_{27}$ and $\mathrm{C}_{28}$ steranes and light carbon isotope, all oils sourced from a mature source rock with the exception of the B Field oil, showed the lower source maturity. This pushed up to think for more investigation in further concessions.

\section{Source Rocks}

TOC Analyses: One hundred and forty interval samples were analyzed for TOC contents (Table 1). The TOC values from B1-NC151 rocks variety between 0.40 to $8.5 \%$, A1-NC186 sediments range between $0.3 \%$ and $1.45 \%$, A1-NC76 range between $0.39 \%$ and $0.74 \%$, D1-NC151 samples have TOC values ranging from $0.40 \%$ to $2.00 \%$ and F1-NC58 have TOC values ranging from $0.40 \%$ to $1.12 \%$. The another wells, D1_ $\mathrm{NC} 174$ has a TOC ranging from $0.30 \%$ to $10 \%$, P1-NC101 samples range between $0.80 \%$ to $1.35 \%$, D1-NC58 samples have TOC range between $0.5 \%$ to $1.10 \%$ and H1-NC58 sediments have range between $0.20 \%$ and $3.50 \%$, while TOC values obtained from the A1-NC58 range between $0.40 \%$ to $1.60 \%$. TOC reflects an organic matter riches of sediments estimated typically using the TOC $w \mathrm{t} \%$. The TOC value of $1.0 \%$ suggested as the lower bound for an effective source sediment, less than $1.0 \%$ cannot produce enough oil and commence key migration, while $0.4 \%$ point to low source rock potential [15]. Hence, the analytical TOC data indicated the occurrence of a major source rock kitchen is Silurian Tanezzuft Formation particularly hot shale member at the base this formation as the principal source rock for wholly studied fields. Other organic source organic matter occurs in the Tanezzuft shales, the inter bedded Devonian shales (Awaynat Wanin Formation) and Carboniferous shales (Mrar Formation) as a result contain sufficient oil prone kerogen to consider as source rock for hydrocarbon [6,7]. Integrated the TOC values and depth of selected source rock from studied basin fields (Figure 2), showed model construction of the basin and topically point to that the rock kitchens (Silurian Tanezzufdt Formation) were occurred in diverse depths, reflecting line of slop into the basin center. The TOC values for assessing richness of organic matter reveled oil generation potential of studied fields range between poor to excellent (Figure 2).

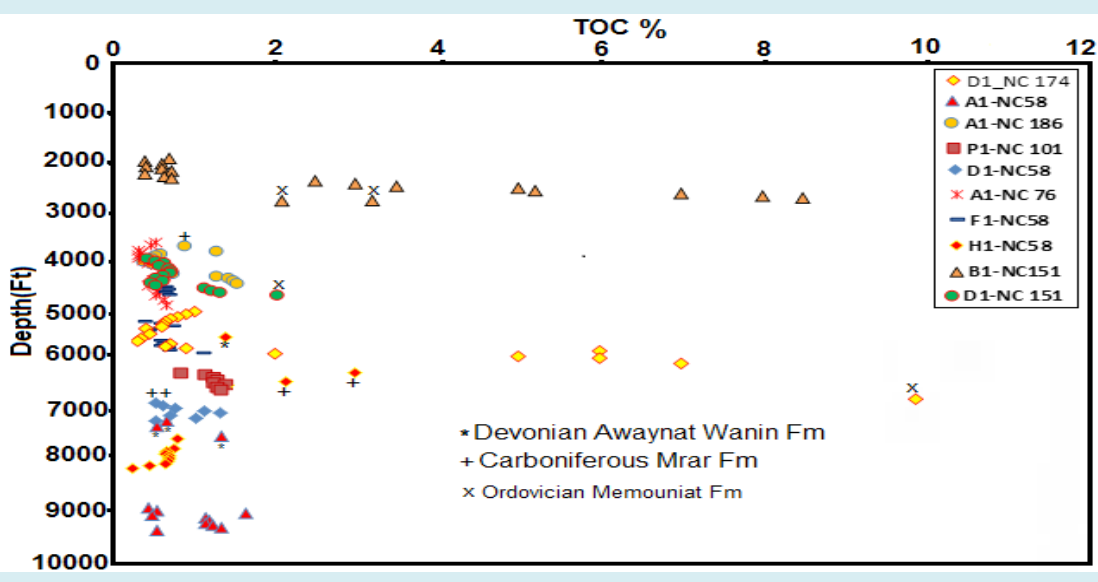

Figure 2: Plot of TOC versus depth for selected source rock collected from the Murzuq Basin. 
Petroleum \& Petrochemical Engineering Journal

\begin{tabular}{|c|c|c|c|c|c|c|c|c|c|}
\hline \multicolumn{2}{|c|}{ F1-NC58 } & \multicolumn{2}{|c|}{ D1-NC 151} & \multicolumn{2}{|c|}{ A1-NC 76} & \multicolumn{2}{|c|}{ D1-NC174 } & \multicolumn{2}{|c|}{ B1-NC151 } \\
\hline TOC & Depth & TOC & Depth & TOC & Depth & TOC & Depth & TOC & Depth \\
\hline 0.65 & 4500 & 0.4 & 3900 & 0.6 & 3550 & 0.9 & 5100 & 0.7 & 1900 \\
\hline 0.68 & 4550 & 0.5 & 3950 & 0.55 & 3600 & 0.8 & 5150 & 0.4 & 1950 \\
\hline 0.66 & 4600 & 0.61 & 4000 & 0.4 & 3700 & 0.7 & 5200 & 0.61 & 2000 \\
\hline 0.7 & 4650 & 0.55 & 4050 & 0.42 & 3750 & 0.65 & 5250 & 0.42 & 2050 \\
\hline 0.4 & 5200 & 0.67 & 4100 & 0.4 & 3800 & 0.62 & 5300 & 0.62 & 2100 \\
\hline 0.6 & 5250 & 0.7 & 4150 & 0.39 & 3850 & 0.6 & 5350 & 0.73 & 2150 \\
\hline 0.75 & 5300 & 0.69 & 4200 & 0.45 & 3900 & 0.4 & 5400 & 0.41 & 2200 \\
\hline 0.46 & 5350 & 0.6 & 4250 & 0.51 & 3950 & 0.45 & 5500 & 0.64 & 2250 \\
\hline 0.45 & 5400 & 0.5 & 4300 & 0.62 & 4000 & 0.35 & 5600 & 0.73 & 2300 \\
\hline 0.6 & 5600 & 0.6 & 4350 & 0.67 & 4100 & 0.3 & 5650 & 2.5 & 2350 \\
\hline 0.63 & 5650 & 0.45 & 4400 & 0.71 & 4200 & 0.7 & 5700 & 3 & 2400 \\
\hline 0.6 & 5700 & 0.5 & 4450 & 0.57 & 4300 & 0.65 & 5750 & 3.5 & 2450 \\
\hline 0.68 & 5750 & 1.1 & 4500 & 0.51 & 4400 & 0.9 & 5800 & 5 & 2500 \\
\hline 0.7 & 5800 & 1.2 & 4550 & 0.63 & 4500 & 6 & 5850 & 5.2 & 2550 \\
\hline \multirow[t]{5}{*}{1.12} & 5850 & 1.3 & 4600 & 0.65 & 4550 & 2 & 5900 & 7 & 2600 \\
\hline & & 2 & 4650 & 0.6 & 4600 & 5 & 5950 & 8 & 2650 \\
\hline & & & & 0.7 & 4700 & 6 & 6000 & 8.5 & 2700 \\
\hline & & & & 0.74 & 4800 & 7 & 6050 & 3.2 & $2750^{x}$ \\
\hline & & & & & & 10 & $6100^{x}$ & 2 & $2800^{x}$ \\
\hline \multicolumn{2}{|c|}{ A1-NC58 } & \multicolumn{2}{|c|}{ H1-NC58 } & \multicolumn{2}{|c|}{ D1-NC 58} & \multicolumn{2}{|c|}{ P1-NC 101 } & \multicolumn{2}{|c|}{ A1-NC 186} \\
\hline TOC & Depth & TOC & Depth & TOC & Depth & TOC & Depth & TOC & Depth \\
\hline 0.75 & $7200 * \mathrm{M}$ & 0.8 & $5750^{*}$ & 0.5 & $6900^{+}$ & 0.8 & 6250 & 0.8 & $3700^{+}$ \\
\hline 0.5 & $7300^{*}$ & 3.5 & $6400^{+}$ & 0.6 & $6950^{+}$ & 1.1 & 6300 & 1.2 & 3750 \\
\hline 1.5 & $7500 *$ & 2 & $6450^{+}$ & 0.75 & 7000 & 1.2 & 6350 & 0.5 & 3800 \\
\hline 0.4 & 8950 & 0.7 & 7800 & 1.1 & 7050 & 1.25 & 6400 & 0.45 & 3850 \\
\hline 0.5 & 9000 & 0.61 & 7850 & 1.3 & 7100 & 1.2 & 6450 & 0.4 & 3900 \\
\hline 1.6 & 9050 & 0.6 & 7900 & 0.68 & 7150 & 1.35 & 6500 & 0.3 & 3950 \\
\hline 0.44 & 9100 & 0.64 & 7950 & 1 & 7200 & 1.25 & 6550 & 0.4 & 4000 \\
\hline 1.1 & 9150 & 0.65 & 8000 & 0.5 & 7250 & 1.3 & 6600 & 0.55 & 4050 \\
\hline 1.15 & 9200 & 0.63 & 8050 & & & & & 0.6 & 4100 \\
\hline \multirow[t]{6}{*}{1.1} & 9250 & 0.6 & 8100 & & & & & 0.62 & 4150 \\
\hline & & 0.4 & 8150 & & & & & 0.65 & 4200 \\
\hline & & 0.2 & 8200 & & & & & 1.2 & 4250 \\
\hline & & & & & & & & 1.35 & 4300 \\
\hline & & & & & & & & 1.4 & 4350 \\
\hline & & & & & & & & 1.45 & 4400 \\
\hline
\end{tabular}

Table 1: TOC data for studied rocks from the Murzuq Basin. 


\section{Petroleum \& Petrochemical Engineering Journal}

Kerogen Type and Environment Description: Data of OI and $\mathrm{HI}$ as kerogen parameters measured for the intervals by Rock Eval pyrolysis confirmed fairly diverse values among studied fields (Table 2). Cross plots of hydrogen index versus oxygen index on modified of Van Kravelen DW [16] diagrams for many source rock samples Figure 3. Obviously, most of the kerogen as predominantly type II oil prone kerogen. Characteristically, the values of $\mathrm{HI}$ and $\mathrm{OI}$ in the cross plot are distributed between the type II and type III kerogen. The kerogen elemental analysis for some representative samples based on Van Kravelen DW [16] diagram is in arrangement with this assessment of the pyrolysis data (Table 2). The base of Silurian Tanezzuft Formation (Hot shale member) naturally holds Type II oil prone kerogen accumulated with over $80 \%$ amorphous organic matter (AOM) and minor quantities of phytoclasts and palynomorphs. This is sign of deposition in a restricted distal marine environment removed from active sources of terrestrial organic matter, supporting by Kerogen elemental analysis data (Table 3). The distinguished exception is well P1-NC101 with only $42 \%$ amorphous organic matter probably due to increase margin of terrestrial organic matter, sourced from assemblage of a Type II/III kerogen. Low HI less than 100 in group samples from few wells (Figure 3) with reasonable of TOC values, maybe due to kerogen degradation and deposition in an oxic/dysoxic water column which reason of decrease in the amount of hydrogen-rich organic matter.

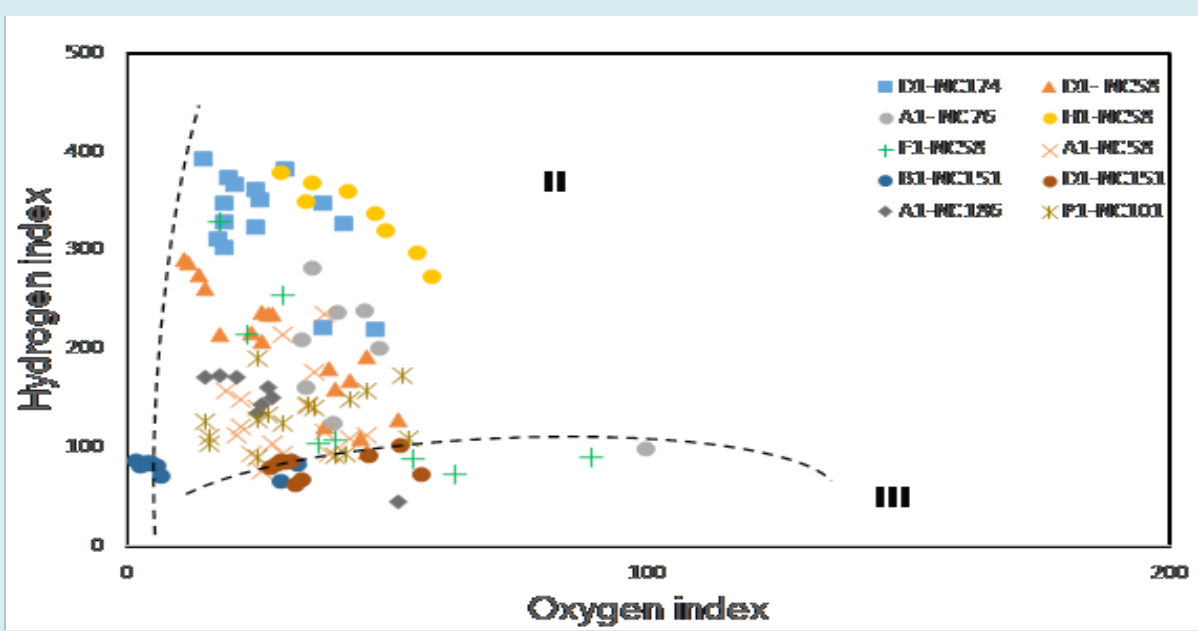

Figure 3: Plot of hydrogen index (HI) versus oxygen index (OI) illustrating the variation of kerogen types in source rocks modified diagrams[16].

\begin{tabular}{|c|c|c|c|c|c|c|c|c|c|}
\hline \multicolumn{2}{|c|}{ D1-NC151 } & \multicolumn{2}{c|}{ D1-NC174 } & \multicolumn{2}{c|}{ P1-NC101 } & \multicolumn{2}{c|}{ D1- NC58 } & \multicolumn{2}{c|}{ A1-NC58 } \\
\hline OI & HI & OI & HI & OI & HI & OI & HI & OI & HI \\
\hline 28 & 79 & 19 & 301 & 53 & 174 & 46 & 96 & 26 & 77 \\
\hline 29 & 82 & 18 & 311 & 46 & 158 & 45 & 109 & 24 & 95 \\
\hline 31 & 84 & 18 & 327 & 43 & 149 & 38 & 122 & 30 & 95 \\
\hline 30 & 85 & 42 & 325 & 54 & 109 & 52 & 128 & 28 & 105 \\
\hline 32 & 86 & 25 & 323 & 42 & 95 & 40 & 160 & 21 & 114 \\
\hline 34 & 67 & 38 & 347 & 40 & 92 & 43 & 169 & 22 & 122 \\
\hline 33 & 61 & 19 & 347 & 25 & 191 & 39 & 181 & 25 & 140 \\
\hline 47 & 90 & 26 & 350 & 25 & 91 & 46 & 192 & 22 & 149 \\
\hline 53 & 101 & 25 & 361 & 15 & 127 & 26 & 209 & 19 & 158 \\
\hline 57 & 72 & 21 & 366 & 16 & 104 & 24 & 217 & 30 & 215 \\
\hline & & 20 & 372 & 16 & 111 & 18 & 215 & 43 & 109 \\
\hline & & 31 & 381 & 25 & 129 & 26 & 238 & 39 & 94 \\
\hline & & 15 & 391 & 27 & 134 & 27 & 236 & 38 & 116 \\
\hline
\end{tabular}


Petroleum \& Petrochemical Engineering Journal

\begin{tabular}{|c|c|c|c|c|c|c|c|c|c|}
\hline & & & & 30 & 126 & 28 & 236 & 46 & 114 \\
\hline & & & & 36 & 140 & 12 & 287 & 35 & 143 \\
\hline & & & & 35 & 145 & 14 & 276 & 36 & 177 \\
\hline & & & & & & 15 & 262 & 38 & 236 \\
\hline & & & & & & 11 & 291 & & \\
\hline \multicolumn{2}{|c|}{ A1-NC186 } & \multicolumn{2}{|c|}{ F1-NC58 } & \multicolumn{2}{|c|}{ H1-NC58 } & \multicolumn{2}{|c|}{ B1-NC151 } & \multicolumn{2}{|c|}{ A1- NC76 } \\
\hline OI & HI & OI & HI & OI & HI & OI & HI & OI & HI \\
\hline 25 & 136 & 18 & 330 & 59 & 272 & 5 & 84 & 36 & 281 \\
\hline 26 & 145 & 30 & 255 & 56 & 297 & 6 & 81 & 41 & 236 \\
\hline 28 & 152 & 37 & 105 & 50 & 318 & 3 & 82 & 46 & 238 \\
\hline 27 & 161 & 40 & 108 & 48 & 337 & 4 & 85 & 34 & 209 \\
\hline 21 & 172 & 63 & 73 & 43 & 359 & 7 & 71 & 49 & 200 \\
\hline 18 & 173 & 89 & 91 & 35 & 348 & 2 & 87 & 35 & 160 \\
\hline \multirow[t]{3}{*}{15} & 172 & 55 & 89 & 36 & 368 & 4 & 83 & 40 & 123 \\
\hline & & 23 & 215 & 30 & 377 & 33 & 81 & 50 & 98 \\
\hline & & & & & & 30 & 65 & & \\
\hline
\end{tabular}

Table 2: Data of OI and HI as kerogen type parameters measured for group of selected intervals by Rock Eval pyrolysis.

\begin{tabular}{|c|c|c|c|c|c|c|}
\hline Well & $\mathbf{\% C}$ & $\mathbf{\% H}$ & $\mathbf{\% 0}$ & $\mathbf{\%} \mathbf{A 0 M}$ & $\mathbf{\%}$ Phytoclasts & \% Palynomorphs \\
\hline D1-NC151 & 18.68 & 1.25 & 4.55 & 88 & 4.3 & 7.5 \\
\hline B1-NC151 & 31.38 & 1.87 & 2.92 & 91.5 & 8.3 & 1.7 \\
\hline D1-NC174 & 24.56 & 2.62 & 3.64 & 93.5 & 4.8 & 3.2 \\
\hline P1-NC101 & n.d & n.d & n.d & 42 & 22.5 & 2.3 \\
\hline H1-NC58 & 35.61 & 2.58 & 2.17 & 82 & 14 & 4.3 \\
\hline A1-NC58 & 12.64 & 1.27 & 6.18 & 92 & 6.5 & 2.2 \\
\hline
\end{tabular}

Table 3: Kerogen elemental analysis data and Kerogen group composition showing the main organic matter constituents contributing to the kerogen. $\mathrm{AOM}=$ Amorphous organic matter, n.d= not determine.

Thermal Maturity Assessment: The Vitrinite reflectance and Tmax are extensively used thermal maturity indicators of kerogen $[17,18]$. Data established from laboratory analyses (Table 4). In this study, the consecutive maturity data is wider to determine a thermaland geologic states arecently discussed such Aboglila S, et al. [6,7]. The measured thermal maturity of the Silurian Tanezzuft Formation, particularly hot shale member indicated diversity of maturation stages. The Tmax values are illustrated in Table 4. Commonly organic matter prone definitive source rocks are mature and will produce oil at Tmax temperature range of $430-460 \mathrm{C}^{\circ}$. The Tmax values of studied fields are confirmed and supported recently studies which published that the Silurian Tanezzuft Formation is the main hydrocarbon sources. A distinguished consequence is a Tmax degree in A1-NC58 well at 7500 feet with $435 \mathrm{C}^{\circ}$ and 1.5 TOC\%, in well D1-NC58 at 6900-6950 feet with 430$435 \mathrm{C}^{\circ}$ and 0.5-0.6 TOC\% and in H1-NC58 well at 5750 feet with $435 \mathrm{C}^{\circ}$ with 0.75 TOC\% while in D1-NC174 well at 6100 feet with $438 \mathrm{C}^{\circ}$ by 10 TOC\% and D1-NC151 well was 446 Co with 2 TOC $\%$ at 4650 feet. These notable results derived from Ordovician Mamuniyat Formation, Carboniferous Marar Formation and Devonian Awaynat Wanin (Table 1 \& Figure 2, above) to clearly established their contribution as a hydrocarbon sources in the basin, even the Ordovician Mamuniyat Formation is lithologic has been classified as a sandstone reservoir in most basin concessions. Furthermore, the Devonian Awaynat Wanin, the Carboniferous Mrar and the Ordovician and Silurian formations are good to very good generative potential source rocks based on of TOC and $\mathrm{S}_{2}$ contents in both Ghadames and Illizi Basins [19]. Spore colour index used as parameter of thermal maturity and/or kerogen composition [12] and illustrated difference values (Table 4). Palynomorphs are uncommon in these samples may due to degradation happening next to initial phase of deposition on the other hand acritarchs distribution for most samples showed increase, could be recognized. Based on 
the association of SCI values to a vitrinite reflectance values and Tmax, the region may by covered a variety of margin maturities, between immature to e mature level in constant with study of Aboglila S, et al. [6].

\begin{tabular}{|c|c|c|c|c|c|c|c|c|c|c|c|}
\hline \multicolumn{3}{|c|}{ D1NC174 } & & \multicolumn{4}{|c|}{ A1N76 } & \multicolumn{4}{|c|}{ D1NC58 } \\
\hline Tmax & $\mathrm{R}_{\mathrm{o}} \%$ & Spore & Depth & Tmax & $\mathbf{R}_{\mathbf{0}} \%$ & Spore & Depth & Tmax & $\mathbf{R}_{\mathrm{o}} \%$ & Spore & Depth \\
\hline & 0.5 & 2.5 & 4500 & & 0.55 & 1.7 & 2950 & 430 & 0.61 & 1.5 & $6900^{+}$ \\
\hline & 0.6 & 2 & 4700 & & 0.5 & 1.5 & 3550 & 435 & 0.65 & 1.7 & $6950^{+}$ \\
\hline & 0.7 & 3 & 4800 & & 0.4 & 1.2 & 3600 & 436 & 0.7 & 2.3 & 7000 \\
\hline & 0.65 & 2.5 & 4950 & 433 & 0.7 & 2 & 4100 & 433 & 0.3 & 2 & 7050 \\
\hline & 0.8 & 1.5 & 5050 & 428 & 0.58 & 2.2 & 4200 & 435 & 0.4 & 2.5 & 7100 \\
\hline & 0.9 & 1.4 & 5100 & 430 & 0.55 & 2.3 & 4300 & 430 & 0.6 & 2 & 7150 \\
\hline & 0.6 & 2.5 & 5250 & 436 & 0.51 & 2.5 & 4400 & 431 & 0.7 & 2 & 7200 \\
\hline & 0.7 & 1.5 & 5300 & 440 & 0.5 & 2 & 4500 & 429 & 0.4 & 2 & 7250 \\
\hline & 0.6 & 1.5 & 5350 & 441 & 0.61 & 1.5 & 4550 & \multicolumn{4}{|c|}{ F1NC58 } \\
\hline & 0.6 & 2.5 & 5400 & 440 & 0.58 & 1.2 & 4600 & Tmax & $\mathbf{R}_{0} \%$ & Spore & Depth \\
\hline 430 & 0.9 & 1 & 5850 & 443 & 1.2 & 2.3 & 4700 & 429 & 0.62 & & 4500 \\
\hline 425 & 1 & 2 & 5900 & 444 & 1.3 & 2.2 & 4800 & & 1.5 & & 5100 \\
\hline 436 & 0.85 & 2 & 5950 & & \multicolumn{3}{|c|}{ H1- NC58 } & 435 & 0.62 & & 5150 \\
\hline 437 & 1.1 & 2 & 6000 & Tmax & $\mathbf{R}_{0} \%$ & Spore & Depth & 427 & 0.6 & & 5200 \\
\hline 439 & 1 & 3.5 & 6050 & 435 & 0.58 & 2 & $7550^{*}$ & 426 & 0.66 & 1.5 & 5250 \\
\hline 438 & 1.14 & 3.3 & $6100^{x}$ & 436 & 0.62 & 3 & 7600 & 425 & 0.68 & & 5450 \\
\hline & & & & 435 & 0.59 & 3 & 7650 & 423 & 0.62 & & 5500 \\
\hline \multicolumn{4}{|c|}{ B1-NC151 } & 439 & 0.6 & 1.5 & 7700 & 426 & 0.66 & & 5550 \\
\hline Tmax & $R_{0} \%$ & Spore & Depth & 440 & 0.65 & 2 & 7750 & 427 & 0.59 & & 5600 \\
\hline 445 & 0.66 & 2 & 2300 & 441 & 0.7 & 2 & 7800 & 428 & 0.64 & 1.4 & 5650 \\
\hline 450 & 0.65 & 3 & 2350 & 438 & 0.66 & 2 & 7850 & 429 & 0.61 & & 5700 \\
\hline 456 & 1.1 & 1 & 2400 & 439 & 0.65 & 2 & 7900 & \multicolumn{4}{|c|}{ D1-NC151 } \\
\hline 458 & 1.5 & 3.5 & 2450 & \multicolumn{4}{|c|}{ A1-NC58 } & Tmax & $\mathbf{R}_{0} \%$ & Spore & Depth \\
\hline 460 & 1.4 & 3 & 2500 & Tmax & $\mathbf{R}_{0} \%$ & Spore & Depth & 445 & 1.1 & 2.5 & 4350 \\
\hline 459 & 1.29 & 3 & 2550 & 435 & 0.5 & 1.5 & $7500^{*}$ & 446 & 1.11 & 2 & 4400 \\
\hline 457 & 1.2 & 3 & 2600 & & & 2.5 & 7550 & 448 & 0.98 & 2 & 4450 \\
\hline 460 & 1.1 & 3.5 & 2650 & & & 2.3 & 8150 & 447 & 1.2 & 2.5 & 4500 \\
\hline 455 & 1.22 & 3 & 2700 & & 1.1 & & 8850 & 446 & 1.3 & 3 & 4550 \\
\hline \multirow[t]{2}{*}{450} & 1.1 & 2 & 2750 & 445 & 1.3 & & 8950 & 448 & 1.2 & 3 & 4600 \\
\hline & 1 & 2 & 2800 & 441 & 1.4 & & 9050 & 446 & 105 & 2 & $4650^{x}$ \\
\hline \multicolumn{4}{|c|}{ P1-NC101 } & 431 & 1.2 & & 9100 & \multicolumn{4}{|c|}{ A1-NC186 } \\
\hline Tmax & $R_{0} \%$ & Spore & Depth & 430 & 1.3 & & 9150 & Tmax & $\mathbf{R}_{0} \%$ & Spore & Depth \\
\hline 420 & & & 6250 & 461 & 1.1 & & 9200 & 432 & & & 3700 \\
\hline 431 & & & 6300 & 428 & 1.2 & & 9250 & 433 & 1.1 & & 3750 \\
\hline 428 & 0.98 & 0.5 & 6350 & 430 & 1.4 & & 9300 & & 0.8 & & 3900 \\
\hline 430 & 1 & & 6400 & 432 & 1,6 & & 9350 & 435 & 0.6 & & 3950 \\
\hline
\end{tabular}


Petroleum \& Petrochemical Engineering Journal

\begin{tabular}{|c|c|c|c|c|c|c|c|c|c|c|c|}
\hline 432 & 1 & 2 & 6450 & 435 & 1.3 & & 9400 & 435 & 0.7 & & 4000 \\
\hline 433 & 1.1 & & 6500 & & & & & 436 & 1.1 & & 4100 \\
\hline 426 & 1.15 & & 6550 & & & & & 435 & 1 & & 4200 \\
\hline 433 & 1.2 & 3.5 & 6600 & & & & & 432 & 0.9 & & 4250 \\
\hline & & & & & & & & 435 & 1 & & 4300 \\
\hline & & & & & & & & 434 & 1.11 & & 4400 \\
\hline
\end{tabular}

Table 4: Vitrinite reflectance, Tmax and Spore colour index as thermal maturity parameters.

Molecular Composition: The analyzed potential source rock samples contained amounts of extractable organic matter (EOM) range relatively from low to rich. The saturated and aromatic hydrocarbons fraction among EOM some samples demonstrated in Figure 4. The gas chromatograms of the saturated hydrocarbon fractions of the EOM showed smooth $n$-alkanes distributions from less $n-\mathrm{C}_{10}$ to more than $n$ - $\mathrm{C}_{35}$ with major common preference (CPI values of around 1.0), consistent with their oil-window maturities indicated by vitrinite reflectance. The pristane to phytane ratios $(>1)$ with dibenzothiophene to phenanthrene ratio (DBT/P $=<$ 1) clearly reveals marine shale and lacustrine environment deposition [20]. The methyldibenzothiophenes to the methylphenanthrenes (MDBT/MP) ratios of around 0.1 show relatively low concentrations of the aromatic sulfur compounds in the aromatic fractions of both the cores analyzed.

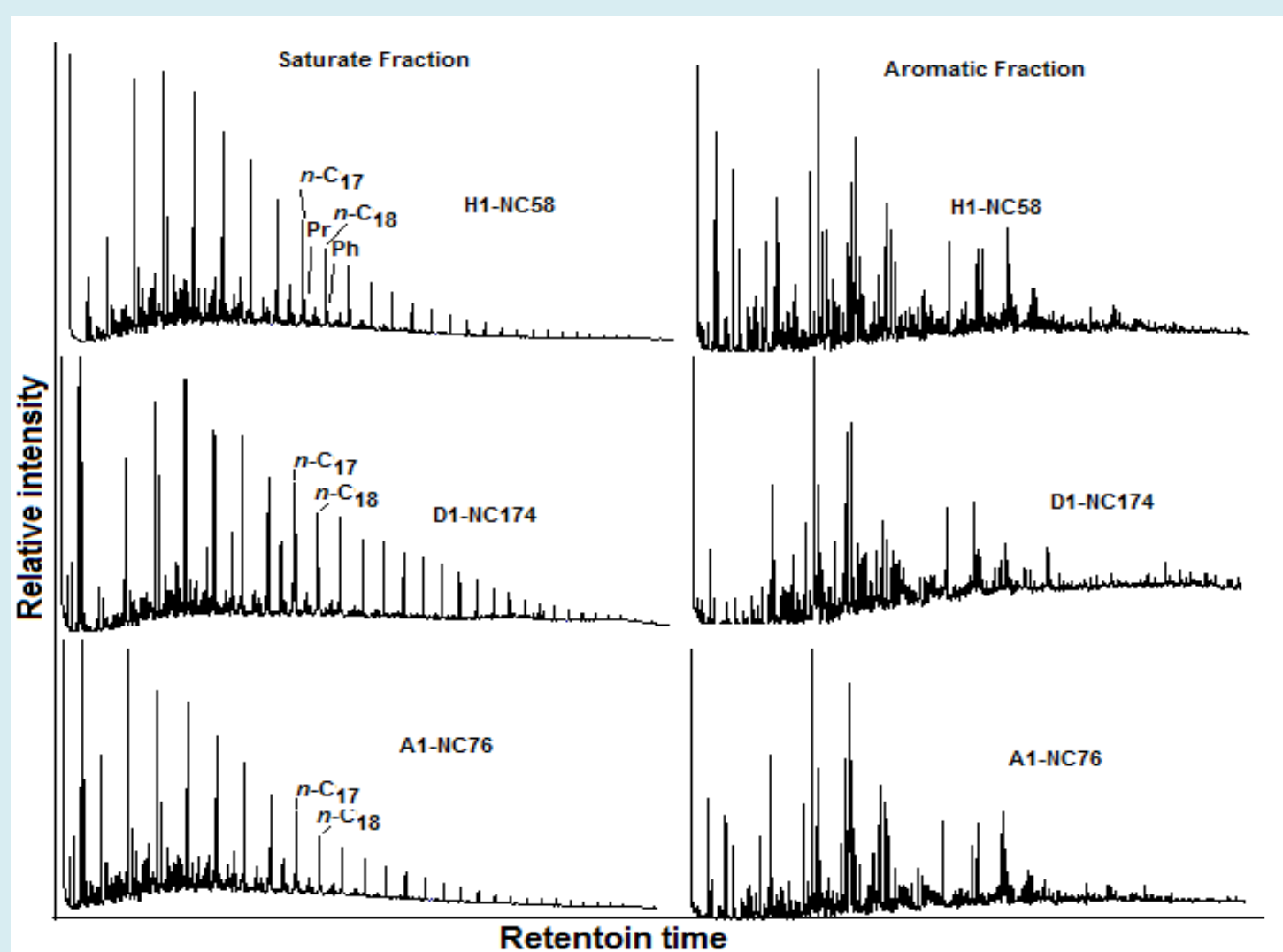

Figure 4: Rock extracts saturated and aromatic hydrocarbon fractions gas chromatograms representing selected samples.

\section{Crude Oils Analysis}

Seven crude oils were collocated from A1-NC186, B1NC186, E2-NC101, F3-NC174, A10-NC115, B10-NC115 and
H10-NC115 for geochemistry analysis. Nitrogen, sulfur and wax content in wt. \% of the crude oil samples were measured and presented in Table 5. The oil sample from E2- 
NC101 illustrated greater wax content among the samples analyzed with low API gravity, to some extent; it indicates a different source comparative to other oils. More detailed in next sections. The low $n-\mathrm{C}_{17}$ to $n-\mathrm{C}_{27}$ ratio of the E2-NC101 oil indicated it increased waxiness compared with the other oils.

Saturated Hydrocarbon: Gas chromatograms of all oils show an abundance of $n$-alkanes $\left(>n-\mathrm{C}_{30}\right)$ such A1-NC186 oil in Figure 5, with exception for the oil of E2-NC101 well, illustrates $\left(<n-\mathrm{C}_{27}\right)$ alkane. The oil of E2-NC101 well has been certainly subjected to some evaporative losses, compared to further analyzed oils. On the other hand, the difference was also shown between oil of E2-NC101 and the further oils in terms of crude oils wax content (Table 5 ). It may clear indication to contribution of compounds generated from marginal plants as the source of E2-NC101 oil. The abundance of $n$-alkanes in the all oils indicates that there have no biodegradation or water washing effects the hydrocarbons. The ratios of pristine $/ n-\mathrm{C}_{17}$, phytane $/ n-\mathrm{C}_{18}$ pristine/phytane and carbon preference index offered in Table 5 are characteristic as several Paleozoic Type II kerogen expelled oils and again the E2-NC101 oil which has much lower pristine/ $n-\mathrm{C}_{17}$ and phytane/ $n-\mathrm{C}_{18}$ ratios than the other oils, additional evidence for different it source.

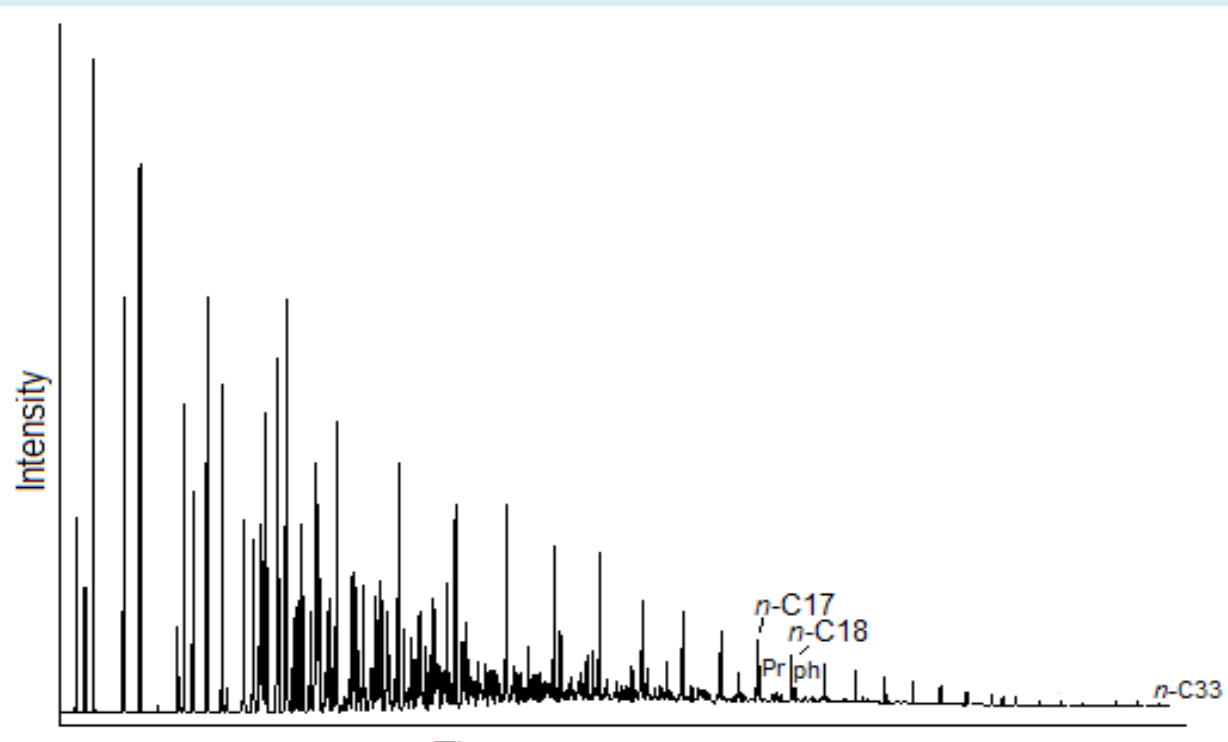

Time

Figure 5: Gas chromatogram of whole oil from A1-NC186 well.

\begin{tabular}{|c|c|c|c|c|c|c|c|c|c|}
\hline Well & $\mathbf{N \%}$ & $\mathbf{S \%}$ & $\mathbf{W a x} \%$ & $\mathbf{P r} / \boldsymbol{n}$-C17 & $\mathbf{P h} / \boldsymbol{n}$-C18 & Pr/Ph & $\boldsymbol{n}$-C17/n-C27 & CPI & API \\
\hline A1-NC186 & 0.34 & 0.31 & 1.85 & 0.63 & 0.45 & 2.22 & 14.69 & 0.99 & 39.5 \\
\hline B1-NC186 & 0.10 & 0.31 & 1.41 & 0.60 & 0.46 & 1.86 & 11.82 & 0.99 & 40.1 \\
\hline E2-NC101 & 0.11 & 0.30 & 6.4 & 0.33 & 0.26 & 1.61 & 6.33 & 1.02 & 30.1 \\
\hline F3-NC174 & 0.31 & 0.30 & 1.90 & 0.69 & 0.51 & 1.89 & 13.23 & 1.03 & 39.1 \\
\hline A10-NC115 & 0.10 & 0.71 & 2.60 & 0.56 & 0.38 & 2.08 & 13.22 & 1.03 & 38.6 \\
\hline B10-NC115 & 0.10 & 0.40 & 2.10 & 0.64 & 0.52 & 1.74 & 10.43 & 0.94 & 39.2 \\
\hline H10-NC115 & 0.29 & 0.15 & 1.25 & 0.57 & 0.39 & 2.27 & 10.80 & 1.00 & 40.2 \\
\hline
\end{tabular}

Table 5: Bulk oil composition and saturated hydrocarbon ratios from whole oil chromatographs.

Aromatic Hydrocarbon Fractions: The gas chromatograms of the aromatic hydrocarbon fractions of oil samples showed characteristic mature crude oil distributions dominated by methylnaphthalenes, dimethylnaphthalenes, trimethylnaphthalenes, methylphenanthrenes and dimethylphenanthrenes peaks. The samples displayed aromatic fraction gas chromatograms typical expelled from mature source rocks. The aromatic hydrocarbons are an indication of organic matter maturity. The majority oils sourced from a mature source rock (Hot shale source) with occur of some oil showed the lower maturity than oils porn from hot shale source, certainly sourced form immature 


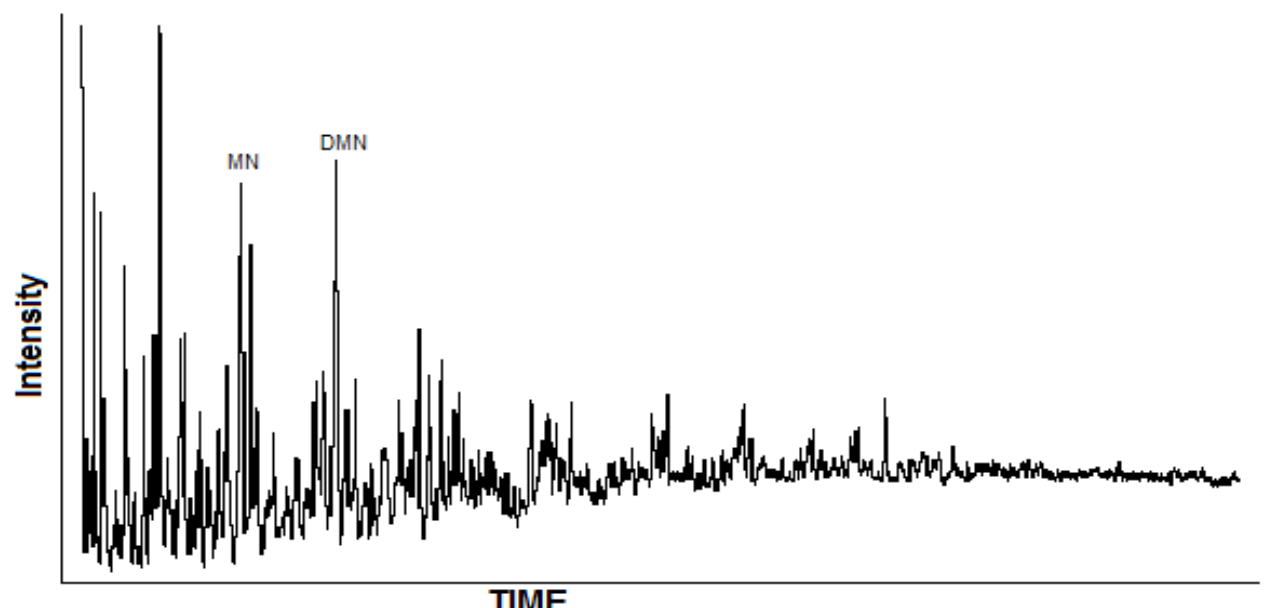

TIME

Figure 6: Gas chromatogram of aromatic hydrocarbon fraction from D1-NC174 sample hydrouspyrolysis.

\section{Stable Carbon Isotope $\left(\delta^{13} \mathrm{C}\right)$ of Rocks and Oils}

The Stable carbon isotope results of seven rock-extract samples and the eight oils were analyzed and displayed data in Table 6. The $\delta^{13} \mathrm{C}$ values of the sediments saturates hydrocarbon fractions ley among $-30.98 \%$ and $-29.14 \%$, while the $\delta^{13} \mathrm{C}$ values of aromatic fractions slightly less negative than those of the saturated hydrocarbon fractions, ranged between $-29.86 \%$ o to $-28.37 \%$.

\begin{tabular}{|c|c|c|c|c|c|c|c|}
\hline \multicolumn{9}{|c}{ Rocks } \\
Saturates & Aromatics & Depth (Ft) & Well & Saturates & Aromatics & Whole Oil & Well \\
\hline-30.98 & -29.69 & 9250 & A1-NC58 & -29.19 & -29.85 & -29.9 & A1-NC186 \\
\hline-29.84 & -29.86 & 5950 & D1-NC174 & -29.32 & -29.98 & -29.82 & B1-NC186 \\
\hline-29.37 & -28.37 & 4650 & D1-NC151 & -28.67 & -29.88 & -29.97 & E2-NC101 \\
\hline-29.15 & -28.98 & 7950 & H1-NC58 & -29.38 & -29.91 & -29.97 & F3-NC174 \\
\hline-30.33 & -29.01 & 6550 & P1-NC 101 & -28.68 & -29.62 & -28.98 & A10-NC115 \\
\hline-29.14 & -28.92 & 2350 & B1-NC151 & -28.92 & -29.83 & -29.84 & B10-NC151 \\
\hline-29.86 & -29.84 & 5750 & F1-NC58 & -29.02 & -29.55 & -29.46 & H10-NC115 \\
\hline & & & & -29.36 & -29.96 & -29.85 & B10-NC115 \\
\hline
\end{tabular}

Table 6: $\delta^{13} \mathrm{C} \%$ of Saturated and aromatic hydrocarbon fraction data of source Rocks and oils.

The $\delta^{13} \mathrm{C}$ values of the oil saturate hydrocarbon fractions showed range between $-29.36 \%$ o to $-28.67 \%$, within about $1 \%$ of the variety of the oils. The $\delta^{13} \mathrm{C}$ data of aromatic were among $-29.98 \%$ to $-29.55 \%$. The Stable carbon isotope results in both rock extractions and crude oils are closer to each other, typical of Paleozoic age.

\section{Oil-Source Rocks Correlations}

Oil-Oil Correlation: The correlation of oil and source rock depends on the biomarker composition to find the genetic relationship between them. Similar biological sources will reveal similar biomarker distributions [21]. An evaluation of the correlations between the oils has been distinguished using a visual assessment of chromatograms together with a comparison of quantified data and ratios. These indicated that most of triterpanes and steranes obtained from the oils are broadly similar Figure 7 and Figure 8. This assumption is supported by carbon stable isotope analysis results (Table 6 above), where there no significant variation among oils, due to dominance of hot shale rock as the main source. The $\mathrm{m} / \mathrm{z} 191$ mass chromatograms of the oils showed prominent 
peaks due to relatively abundant tricylic terpanes, typically the $\mathrm{C}_{23}$ tricylic terpane that was often more abundant than the $\mathrm{C}_{30}$ hopane peak. The prominence of tricylic terpanes relative to hopanes in oils is correspondingly recognized due increase in maturity [22]. Peaks of disteranes in the $\mathrm{m} / \mathrm{z}$ 217 mass chromatograms are also more abundant than the chain steranes $\left(\mathrm{C}_{27}-\mathrm{C}_{29}\right)$ in oils, this also can describe as an influence of maturity.

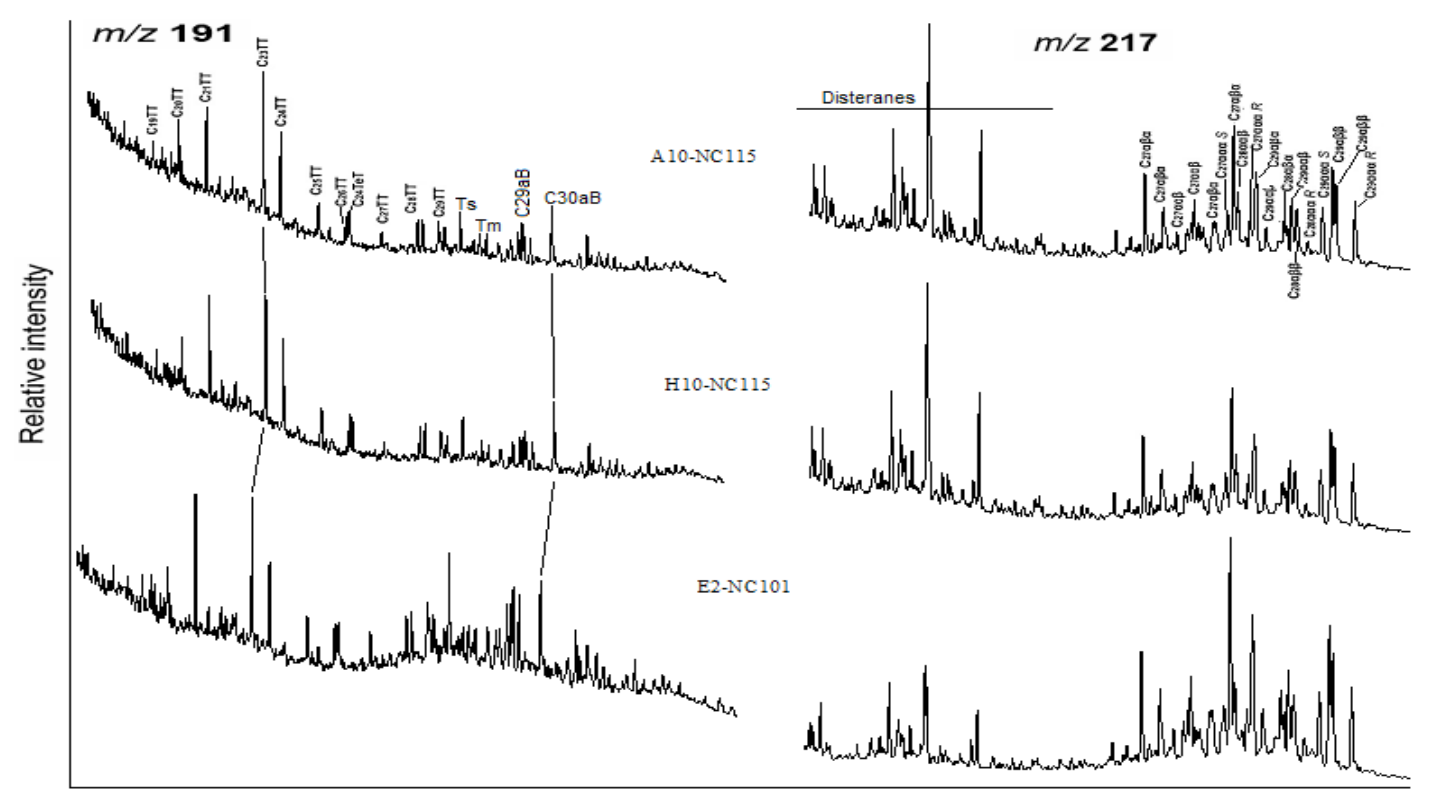

Relative retention time

Figure 7: Biomarkers distribution (m/z 191 and 217) of selected oil samples.

Oil-Source Rocks Correlations: The correlations between the studied oils and potential source rocks has been showed in the preceding sections using a visual assessment of chromatograms together with a comparison of quantified data and ratios calculated triterpanes and hopanes peaks and illustrated in Figure 8. Data indicated that most of the core extracts were broadly similar to most of the oils with some increases in oils data, possible due to development oil maturity and/or a status of mixing in reservoir. The carbon stable isotope results are again confirming this notion.

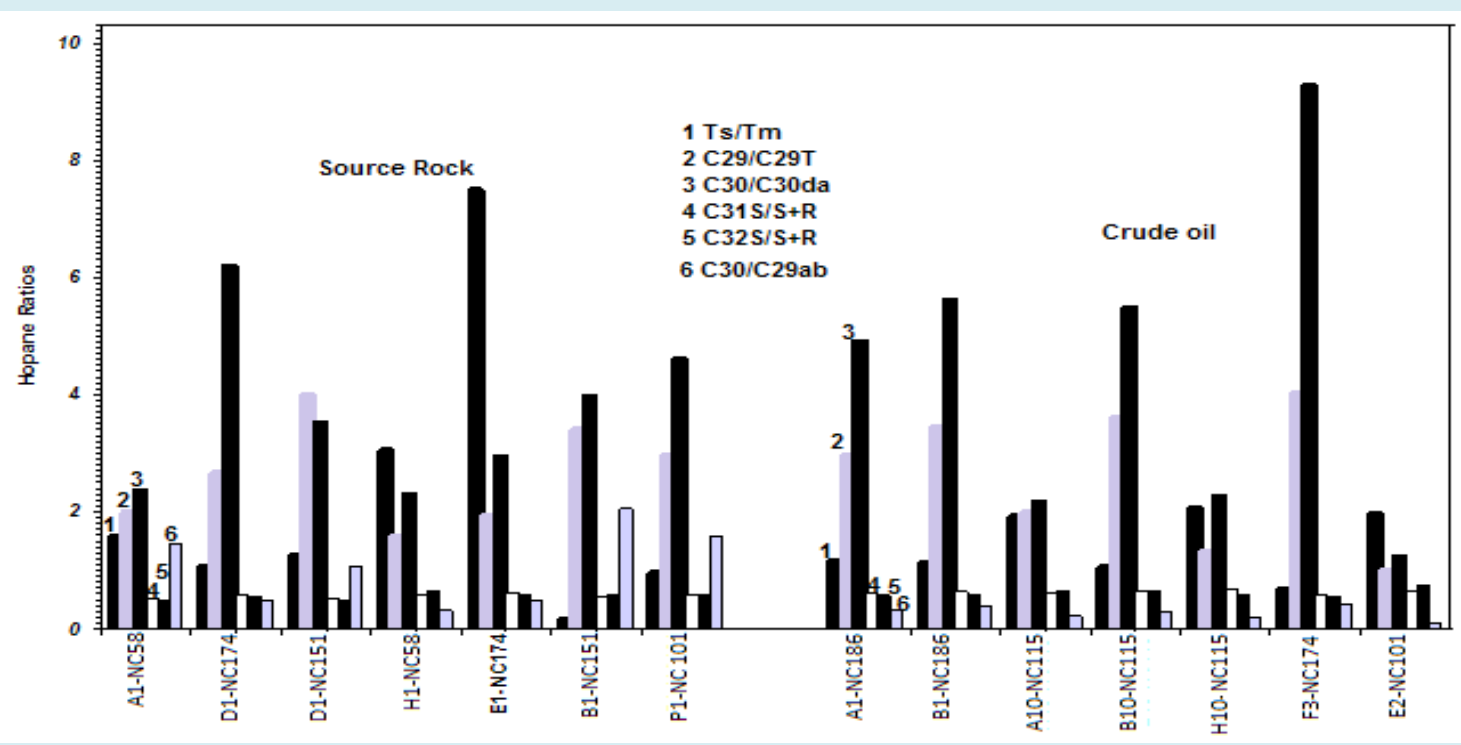

Figure 8: Biomarkers (hopanes ratios) correlation between the crude oils and source rocks samples. 
The Figure 9 display a correlation between saturated, aromatic fractions and whole oil $\delta^{13} \mathrm{C}$ fingerprint of the analyzed oil samples. The whole oil samples analyzed are convergent $\delta^{13} \mathrm{C}$ values, the $\delta^{13} \mathrm{C}$ of saturated hydrocarbon fractions showed flat values and $\delta^{13} \mathrm{C}$ data of the aromatic fractions displayed closer to each other (Figure 9). The similarity of the $\delta^{13} \mathrm{C}$ values of the oils suggest clear correlation between region hydrocarbons, in terms of era time where light $\delta^{13} \mathrm{C}$ data indicate Paleozoic Era and the domination of single source, with exist of other contribution sources. In most cases, the distribution of the $\mathrm{d} 13 \mathrm{C}$ value is roughly similar between the crude oil and the organic matter extracted from studied rocks, showed a light values and indication of inheritance of Paleozoic Era. The above clearly indicates a genetic relationship between of both crude oils and the organic matter extracted from studied rocks.

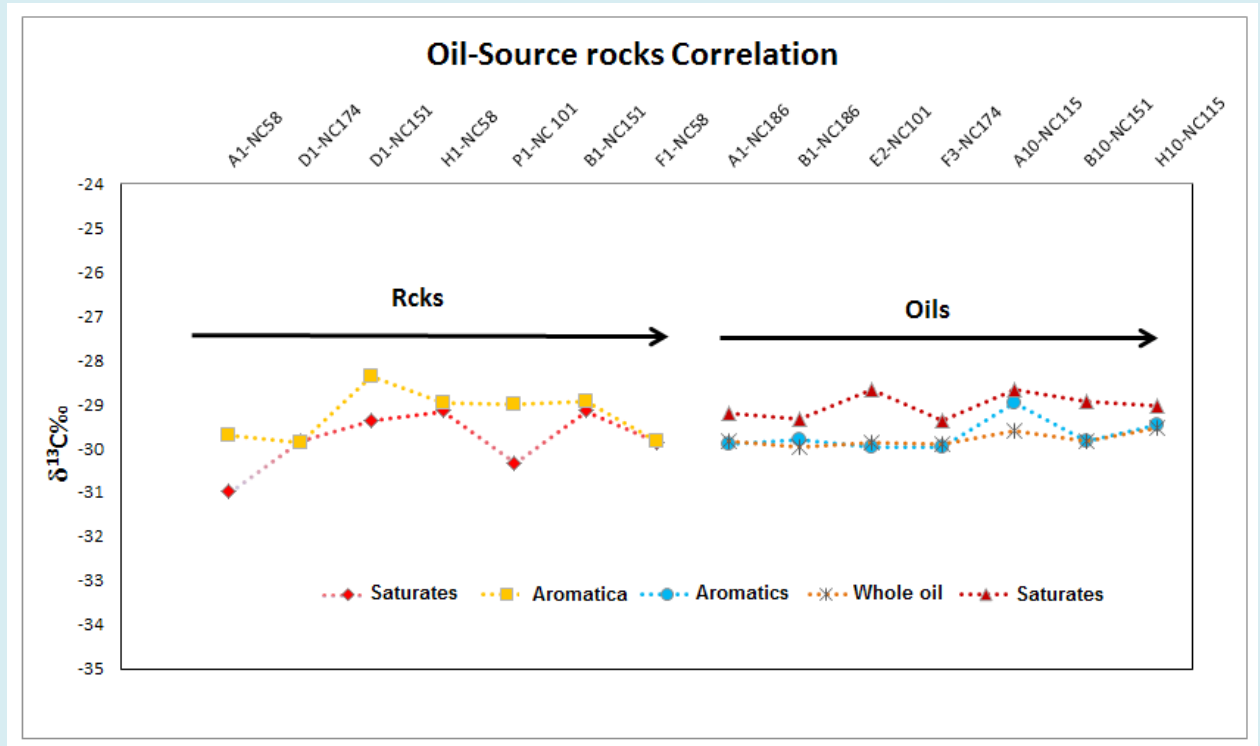

Figure 9: Stable carbon isotope fingerprint of the selected rocks and oils from studied wells in Murzuq Basin.

\section{Conclusion}

The data confirmed that the hot shale facies at the base of the Silurian Tanezzuft Formation as the principal source rock for Murzuq Basin. Although other organic rich facies occur in the rest of the Paleozoic Era as well as in the Devonian, and Carboniferous strata their source potential and Ordovician Mamuniyat Formation could be expected. The hot shale typically contains Type II/III oil prone kerogen with high amorphous organic matter and negligible amounts of phytoclasts and palynomorphs, advising deposition in a restricted distal marine environment might remove from active sources of terrestrial organic matter. The hot shale is typically a rich source rock characterized by high TOC content, suggesting its very good initial source potential. Thermal maturity of the hot shale indicated a wide range of maturities between early oil generations to post oil generation base on Ro\% values. The oil biomarkers are characterized by low abundances of triterpanes and steranes, with dominance of $\mathrm{C}_{29}$ steranes, which is typical of mature Paleozoic oils. The Stable carbon isotope results in both rock extractions and crude oils are closer to each other, typical of Paleozoic age.

\section{References}

1. Hallett D (2002) Petroleum Geology of Libya. $1^{\text {st }}($ Edn.), Elsevier Science Limited, Kidlington.

2. Archer R (1999) Thermal maturity and source quality in selected wells from Murzuq Basin. Geochem Associates, LASMO, pp: 15.

3. Aziz A (2000) Stratigraphy and hydrocarbon potential of the Lower Paleozoic succession of License NC-115, Murzuq Basin, SW Libya. In: Sola MA, Worsley D (Eds.), Geological Exploration in the Murzuq Basin. Elsevier Science B.V, pp: 349-368.

4. Echikh K, Sola MA (2000) Geology and Hydrocarbon Occurrences in the Murzuq Basin, SW Libya. In: Sola MA, Worsley D (Eds.), Geological Exploration in the Murzuq Basin. Elsevier Science B.V, pp: 175-222.

5. Harman R (1999) Geochemical analysis and thermal history modeling of concession NC174 in Murzuq Basin, southwest Libya. Graham \& Trotman Ltd, London, pp; 269-286. 


\section{Petroleum \& Petrochemical Engineering Journal}

6. Aboglila S, Elaalem M, EzlitY, Farifr E (2018) Geochemical characteristics of six formations based on organic geochemical parameters. Murzuq Basin, Libya. Advances in Research 15(4): 1-11.

7. Aboglila S, Abdulgader A, Albaghdady A, Hlal O, Farifr E (2019) Biomarker Ratios and Stable carbon Isotopes to Describe Crude Oils Characteristics in the Murzuq Basin (Libya). Advances in Research 18(3): 1-12.

8. Meister EM, Ortiz EF, Pierobon EST, Arruda AA, Olivira AM (1991) The origin and migration fairways of petroleum in the Murzuq Basin, Libya. The Geology of Libya, Elsevier, Amsterdam, 7: 2725-2742.

9. Davidson L, Beswetherick S, Craig J, Eales M, Fisher A, et al. (2000) The structure, stratigraphy and petroleum geology of the Murzuq Basin, southwest Libya. In: Basin MA, Sola, Worsley D (Eds.), Geological Exploration in the Murzuq. Elsevier Science, pp: 295-320.

10. Walko $P$ (1994) A geochemical study involving samples from NC174 in the Murzuq Basin of southwest Libya. Geochem Group, LASMO, UK.

11. Rusk DC (2001) Libya: Petroleum potential of the underexplored basin centers. In: Downey MW, Threet JC, Morgan WA (Eds.), Petroleum provinces of the twentyfirst century. AAPG Memoir 74: 429-452.

12. Collins A (1990) The 1-10 spore colour index (SCI) scale: A universally applicable colour maturation scale, based on graded, picked palynomorphs. In: Fermont WJJ, Weegink JW (Eds.), Proceedings of the International Symposium on Organic Petrology. Rijks Geologische Dienst, Zeist, the Netherlands, 45: 39-47.

13. Bastow TP, Van Aarssen BG, Lang D (2007) Rapid small-scale separation of saturate, aromatic and polar components in petroleum. Organic Geochemistry 38(8): 1235-1250.
14. El Diasty WS, El Beialy S, Anwari T, Batten D (2017) Hydrocarbon source potential of the Tanezzuft Formation, Murzuq Basin, south-west Libya: An organic geochemical approach. Journal of African Earth Sciences 130: 102-109.

15. Abu Bakr F, Mohamed AM (2008) Nature of Organic Matter, Thermal Maturation and Hydrocarbon Potentiality of Khatatba Formation at East Abu-gharadig Basin, North Western Desert, Egypt. Australian Journal of Basic and Applied Sciences 2(2): 194-209.

16. Van Kravelen DW (1961) Coal. Elsevier, Amsterdam.

17. Tissot B, Welte DH (1984) Petroleum Formation and Occurrence. $2^{\text {nd }}(E d n$.$) , Springer-Verlag, Berlin and New$ York, pp: 702.

18. Landais $P$ (1996) Petroleum geochemistry and geology. $2^{\text {nd }}(E d n$.$) , American Chemical Society, pp: 743$.

19. Akrout D, Hassene A, Riadh A, Eric M, Mabrouk M (2011) Source Rock Characterization and Petroleum Systems in North Ghadames Basin, Southern Tunisia. Resource Geology 61(3): 270-280.

20. Hughes WB, Holba AG, Dzou LIP (1995) The ratios of dibenzothiophene to phenanthrene and pristane to phytaneas indicators of depositional environment and lithology of petroleum source rocks. Geochimica et Cosmochimica Acta 59(17): 3581-3598.

21. Peteres KE, Moldowan JM (1993) The biomarker guide: interpreting molecular fossils in petroleum and ancient sediments. Englewood Cliffs, New Jersey, USA.

22. Peters KE, Moldowan JM, Sundararaman P (1990) Effects of hydrous pyrolysis on biomarker thermal maturity parameters: Monterey phosphatic and siliceous members. Organic Geochemistry 15(3): 249-265. 